Supplement of Atmos. Chem. Phys., 21, 4103-4121, 2021

https://doi.org/10.5194/acp-21-4103-2021-supplement

(C) Author(s) 2021. CC BY 4.0 License.

(c) (i)

Supplement of

\title{
Simulations of anthropogenic bromoform indicate high emissions at the coast of East Asia
}

Josefine Maas et al.

Correspondence to: Susann Tegtmeier (susann.tegtmeier@usask.ca)

The copyright of individual parts of the supplement might differ from the article licence. 


\section{Supplement}

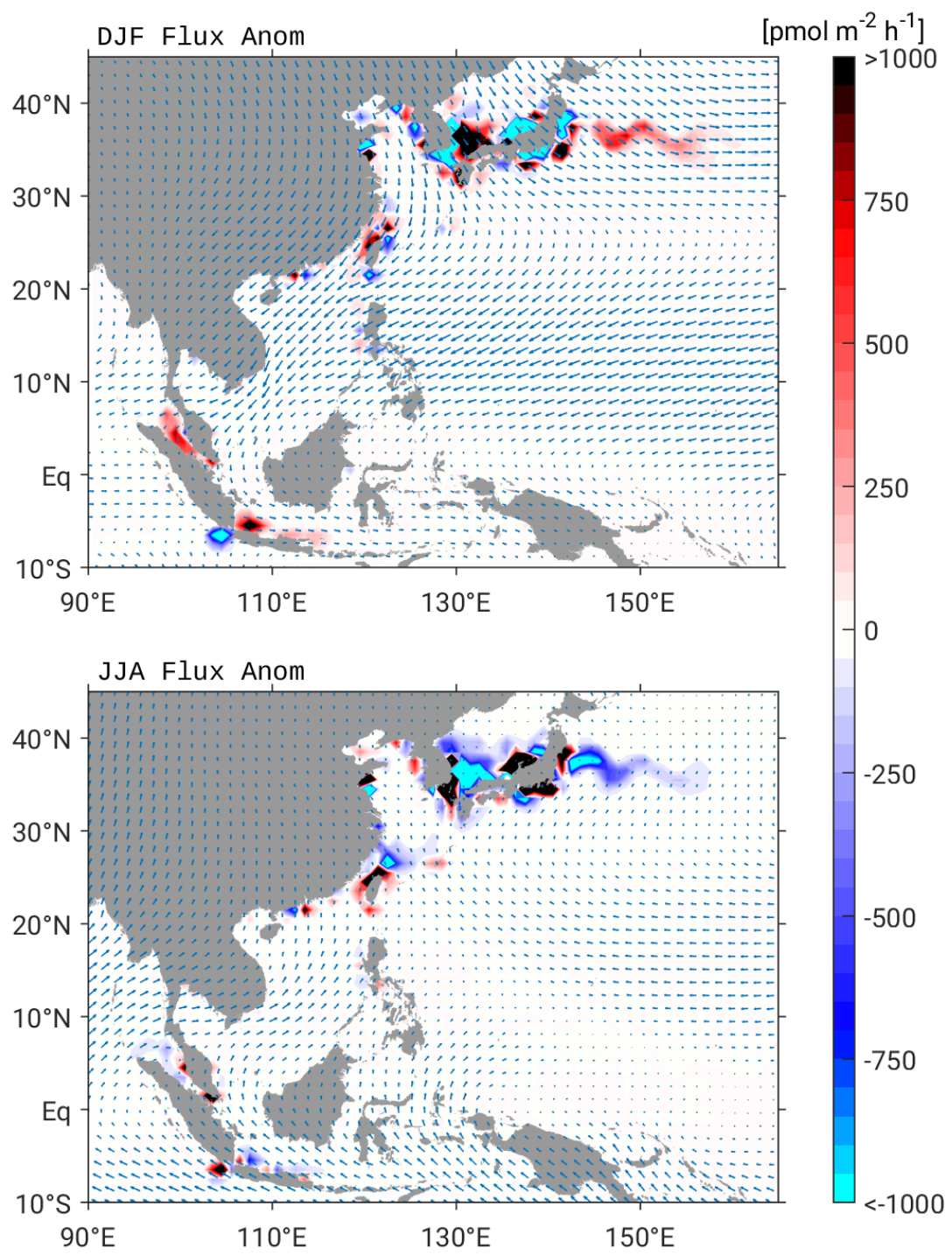

Figure S1: Seasonal anomaly of sea-air flux for the MODERATE scenario in boreal winter (DJF) and summer (JJA) (in pmol $\mathrm{m}^{-2} \mathrm{~h}^{-1}$ ). Blue arrows show the seasonal mean surface winds from the forcing data of the simulation time period. 


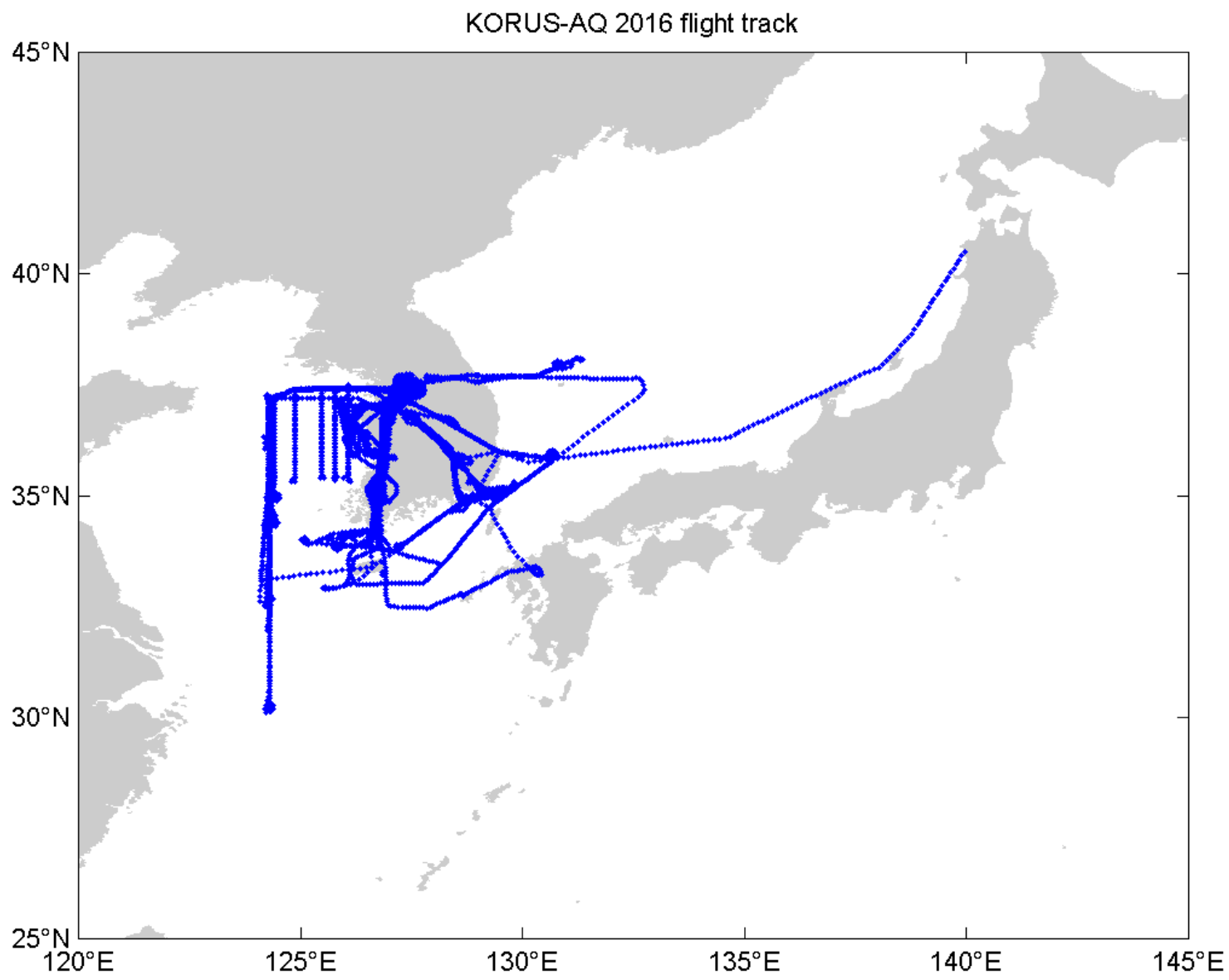

Figure S2: Flight track of the airborne bromoform measurements from the KORUS-AQ campaign in May-June 2016 over South Korea.

Table S1: Average atmospheric mixing ratios [ppt] from Ziska2013+MODERATE and Ziska2013 in the UTLS are given as the mean and the standard deviation over the largest $90 \%$ (referred to as mean values) and over the largest $10 \%$ (referred to as maximum values).

\begin{tabular}{l|l|l|l|l}
\hline \multirow{2}{*}{ Scenario } & \multicolumn{3}{c}{ Atmospheric mixing ratio [ppt] in the UTLS } \\
\cline { 2 - 5 } & \multicolumn{2}{|c}{ JJA } & \multicolumn{2}{c}{ DJF } \\
\hline & $90 \%$ & $10 \%$ & $90 \%$ & $10 \%$ \\
\hline Ziska2013+MODERATE & $0.20 \pm 0.07$ & $0.38 \pm 0.04$ & $0.22 \pm 0.07$ & $0.39 \pm 0.04$ \\
\hline Ziska2013 & $0.15 \pm 0.05$ & $0.27 \pm 0.03$ & $0.18 \pm 0.05$ & $0.28 \pm 0.02$ \\
\hline
\end{tabular}

